\title{
Design Architecture of a Student Co-curricular Activity Management Platform
}

\author{
Fernandino S. Perilla, Alvin R Malicdem
}

\begin{abstract}
This paper introduces a design architecture of a co-curricular activity management platform for students. Because of the absence of features in existing learning management platforms to manage co-curricular activities that educational institutions have to offer, these learning management platforms are not fitted to be utilized. One of the essential circumstances for raising qualified and prepared students in this day and age is to guarantee their interest and participation in social activities. In the education aspect, social activities are co-curricular activities earlier known as extracurricular activities, which are components of non-academic curriculum that helps to create different facets of character improvement of students.

Quantitative research particularly descriptive research using survey questionnaires and guided interviews, Intensive literature review on published studies and articles, and latest information technology reviews were conducted to come up with an appropriate design architecture to improve student's engagement in co-curricular activities.

Integrating the ideas and insights gathered on the conducted study, a new design architecture for a co-curricular activity management platform was proposed. In order to evolve architecture continually, the new design provided greater flexibility for development teams that decreases development cycle times by allowing them to update modules of the platform independently without affecting the other parts, and also the design responded to the needs of the users, and integrated emerging ICT trends. The tailor fitted design architecture of the platform addressed the specific needs of its end-users, thus providing students more convenient experience and opportunities to engage in co-curricular activities provided by higher educational institutions.
\end{abstract}

Index Terms - co-curricular activities, design architecture, learning management platforms, student engagement.

\section{INTRODUCTION}

The government and higher educational institutions had focused on the imperative role played by student engagement and encouraged students to enthusiastically participate in activities in their program, making the importance of engagement reflected positively to their academic outcomes like progression, retention and completion. Thus, researches in areas that indicate learning experiences on technologies that support learning platforms, education, and course structure have been undertaken [1]. In significant investigations, it is proposed to compose, increment, and disperse social activities reasonable for students' dynamic interest to help their passion, aesthetic and creative

knowledge, improve their social experiences and affective perspectives, and empower them to convey what needs be [2]. Higher educational institutions are the focal destination for the advancement of students' well-being and by primary developmental context, are and essential formative setting where numerous concerns emerge and can be viably tended to [3] [4] [5].

Along these lines, notwithstanding information and academic skills, they are even more urged to give explicit support to help build up students' social-emotional competence, for example, impulse control and stress management, seeking help (self-administration); distinguishing and perceiving feelings, self-adequacy (mindfulness); critical thinking, individual, social, and moral duty (responsible decision-making); relationship building, communication (relationship aptitudes); and compassion, regard for other people (social awareness) [6].

One of the essential circumstances for raising qualified and prepared students in this day and age is to guarantee their interest and participation in social activities. In the education aspect, social activities are co-curricular activities earlier known as extracurricular activities, which are components of non-academic curriculum that helps to create different facets of character improvement of students. There is a need of enthusiastic, spiritual, moral and physical development that is supplemented and enhanced by co-curricular activities for the all-around development of the students [7]. These activities, which individuals take an interest in during their spare time, empower them to build up a solid character and have a good quality of life by improving their intellectual, emotional, and physical prosperity [8]. Social activities allude to all happenings that students do in the logical, cultural, social, artistic, and sports fields to gain new interests and talents [9]. In this manner, students figure out how to endure various contemplations, convictions, and cultural qualities [10], increase new values, and create self-control mechanisms [11]. Moreover, social activities additionally bolster advancement of emotional learning aptitudes in students [12].

Involvement in co-curricular activities likewise empowers students to build up their critical thinking, skills of self-expression, cooperative work, assuming liability, arranged work, and effective communication [13]. Association in co-curricular activities likewise underpins development of social emotional learning aptitudes in a student. Social emotional learning is a mind boggling and multilateral skill existing inside all components of life which 
comprises of emotional insight, social knowledge and social-emotional capability [14], also, it is the process of managing, organizing and recognizing emotions, right decision making, taking responsibility, having empathy, acting fairly and ethically, and evading undesirable behaviors so that students can accomplish their life's responsibilities [15] [16]. Students with developed social emotional learning skills learn to reject unsuitable requests, develop empathy, behave more autonomously, establish healthy relationships, do collaborative works and respects other individual's emotions and rights [17]. Studies have accentuated that students with high level of social emotional learning aptitudes have higher scholastic accomplishments and learning desires as well as cutting edge critical thinking abilities [18].

Student's course study information is provided via some learning platforms such as Edmodo, Blackboard, Schoology, and Moodle by higher educational institutions [19]. These platforms enable students to upload their assignments, download and browse supplemental learning materials, view announcements submitted by teachers or module tutors, and view grades and among all other components that are related to students. However, there are restraints on the features of these platforms as it cannot be utilized in the management of co-curricular activities that the educational institution has to offer. Organizations that facilitate co-curricular activities cannot promote their programs through these platforms. For instance, the organizers cannot get in touch with their target participants, and cannot guarantee wide broadcasting of information regarding their activities because the current environment of these platforms do not provide this kind of services. Students that are not engaging in co-curricular activities will badly affect their progression during their study. As a result, issues like these may lead to some students to fail in their courses.

Therefore, this study steered beach marking on different learning management platforms and conducted evaluation if these systems incorporated co-curricular activity management features. Also, this study looked into the user and system requirements as inputs in the design architecture of a platform that will manage co-curricular activities for students. The proposed idea is to integrate the co-curricular activity management platform with data mining, analysis, and notification features so that student's engagement with co-curricular activities can be better tracked and intervention can be made where appropriate. The most significant aim of the new design architecture of the platform is to improve the education quality of the current higher education learning systems and provide the students with relevant educational experiences in a well-organized method.

\section{MATERIALS AND METHODS}

An in-depth literature review was employed to collect significant insights about learning management platforms and co-curricular activity management platforms. Key terms such as 'learning platforms', 'learning management platforms, 'co-curricular platforms', 'co-curricular activity management', 'student engagements', and 'design architecture' were used to draw scholarly works and articles on academic databases, then were studied comprehensively to understand its paradigm. The second review involved the

evaluation and comparison of existing learning management platform. These platforms were evaluated by examining its general structure, features, and whether these are capable to be used and be implemented in management of co-curricular activities by organizations in higher educational institutions.

The researcher also utilized quantitative research particularly descriptive research using personal guided interview survey that involved co-curricular activity organizers to explore their ideas and determine the problems that they encounter in managing co-curricular activities. These were used as ideas in the design architecture of the co-curricular activity platform. End-users, IT experts, and consultants were also considered to gather more and deeper insights like the features and provisions that the design architecture of a co-curricular activity management platform should be integrated. Review on the latest development tools, techniques, and technologies that can be adopted was also initiated to ensure the right specification of the platform to be implemented.

\section{RESULTS AND DISCUSSION}

\section{A. Existing learning platforms evaluation}

In recent years, numerous papers were published evaluating different learning management platforms. Lewis, B. A., et. al. (2005) compared nine learning management systems and highlighted the product features which enhances the platforms' ability to accommodate active learning. Their evaluation on learning management platforms did not include criteria for the learning management platforms' capability to support co-curricular activity management. It is also emphasized in their study that learning management platforms should include features that enables communication, collaboration, as well as community building [20]. Table 1 shows the learning management platforms that were evaluated by Lewis, B.A., et. al. and the features they considered as criteria in the evaluation of the different platforms.

Table 1. Lewis, B. A., et. al. learning management platforms and feature evaluation criteria.

\begin{tabular}{|l|l|}
\hline $\begin{array}{c}\text { Evaluated Learning } \\
\text { Management } \\
\text { Platforms }\end{array}$ & $\begin{array}{c}\text { Learning Management } \\
\text { Platforms' } \begin{array}{c}\text { feature evaluation } \\
\text { criteria }\end{array}\end{array}$ \\
\hline $\begin{array}{l}\text { WebCT Campus Ed. } \\
\text {.1 }\end{array}$ & $\begin{array}{l}\text { Bulletin Boards/Discussion } \\
\text { Area }\end{array}$ \\
\hline Blackboard 6.2 & Group Participation \\
\hline Jones E-education & Calendar \\
\hline Educator & Chat/Whiteboard/E-mail \\
\hline Angel & Student Study Tools \\
\hline LRN & Audio/Video \\
\hline $\begin{array}{l}\text { McGraw Hill Page } \\
\text { Out }\end{array}$ & $\begin{array}{l}\text { Monitoring Student } \\
\text { Participation and Progress }\end{array}$ \\
\hline Moodle & Navigation and Interface \\
\hline E-College & Site Administration \\
\hline E-College AU & \\
\hline
\end{tabular}


Comparing papers published in different years, Kljun, M., et. al. (2007) tried to find out if a pattern can be drawn on the features linked to a certain time period, the evolution and demand for new features through time, and how authors and learning management platform developers respond to these demands. Included on their paper also, are the present demands and features to be integrated on future versions of learning management platforms but there was nothing mentioned on the need of integrating features to accommodate co-curricular activity management [21]. Table 2 presents the criteria used to evaluate learning management platforms in their study.

Due to absence of literature and published articles that evaluated learning management platforms on its capability to support co-curricular activity management, the researcher conducted further literature review, and evaluated the best learning management platforms for 2018 [22]. Base on the evaluation conducted by the researcher, it was found out that all existing learning platforms available in the market today don't have features that support co-curricular activity management. Majority of learning management platforms are limited only with classroom learning management, like student study tools, monitoring student participation and progress, course content management, and among all other components that are related to student classroom learning. Presented on table 3 are the top 9 learning management platforms as published by pcmag.com and their co-curricular management feature evaluation conducted by the researcher.

Table 2. Kljun, M., et. al learning management platforms feature evaluation criteria.

\begin{tabular}{|l|}
\hline Learning Management Platforms Evaluation Criteria \\
\hline 1. Content \\
\hline 2. Communication \\
\hline 3. Environment \\
\hline 4. Collaboration \\
\hline 5. Educational tools \\
\hline 6. Management tools \\
\hline 7. Technical characteristics \\
\hline
\end{tabular}

Table 3. Top learning management platforms [22] and their support to co-curricular activity management evaluation.

\begin{tabular}{|l|c|}
\hline $\begin{array}{c}\text { Learning Management } \\
\text { System }\end{array}$ & $\begin{array}{c}\text { Support to Co-curricular } \\
\text { Activity Management }\end{array}$ \\
\hline 1. Absorb & Not supported \\
\hline 2. Schoology & Not supported \\
\hline 3. Instructure Canvas & Not supported \\
\hline 4. Moodle & Not supported \\
\hline 5. Blackboard Learn & Not supported \\
\hline 6. D2L Brightspace & Not supported \\
\hline 7. Edmodo & Not supported \\
\hline 8. Quizlet & Not supported \\
\hline 9. Google Classroom & Not supported \\
\hline
\end{tabular}

\section{B. User and system Requirements}

Understanding user and system requirements are fundamental in designing and developing accurate software systems. The researcher managed to capture the user and system requirements presented in tables 4 and 5 via guided interviews and gathered the use-cases (presented in figure 1) related to the scenarios from the intended target users.

Table 4 shows the identified user requirements report and table 5 shows the summary of identified system requirements based on the guided interviews conducted among the activity organizers, students, IT experts, and consultants. The following information were then used as inputs in constructing the design architecture of a co-curricular activity management platform

Table 4. Summary of identified user requirements

\begin{tabular}{|c|}
\hline User Type: Student \\
\hline The system shall be accessible in mobile devices \\
\hline $\begin{array}{l}\text { The system shall have notifications on new activities } \\
\text { posted by organizers }\end{array}$ \\
\hline $\begin{array}{l}\text { Notifications received shall be based on the interests that } \\
\text { users have chosen during the registration process }\end{array}$ \\
\hline $\begin{array}{l}\text { The system shall have an "event reminder" to notify users } \\
\text { on upcoming activities that the students are required to } \\
\text { participate }\end{array}$ \\
\hline $\begin{array}{l}\text { The system shall be able to display students that signed-up } \\
\text { to the same activity }\end{array}$ \\
\hline $\begin{array}{l}\text { Registration shall be required for students to access the } \\
\text { system }\end{array}$ \\
\hline User Type: Activity Organizer \\
\hline $\begin{array}{l}\text { The system shall have a separate provision or account for } \\
\text { event or activity organizers }\end{array}$ \\
\hline $\begin{array}{l}\text { The system shall be able disseminate information of new } \\
\text { activities to specific target students }\end{array}$ \\
\hline $\begin{array}{l}\text { The system shall be able to track participan } \\
\text { interested in particular activity or event }\end{array}$ \\
\hline $\begin{array}{l}\text { The system shall be able to let the participants evaluate the } \\
\text { activities and send feedbacks }\end{array}$ \\
\hline $\begin{array}{l}\text { The system shall be able to send updates and notifications } \\
\text { to participants }\end{array}$ \\
\hline User Type: System Administrator \\
\hline $\begin{array}{l}\text { The system shall allow registration and verification of new } \\
\text { organizations and event organizers }\end{array}$ \\
\hline $\begin{array}{l}\text { The system shall verify activities and events created by } \\
\text { organizations and event organizers before posting }\end{array}$ \\
\hline The system shall verify student registration \\
\hline $\begin{array}{l}\text { The system shall allow creation of new system } \\
\text { administrators }\end{array}$ \\
\hline
\end{tabular}




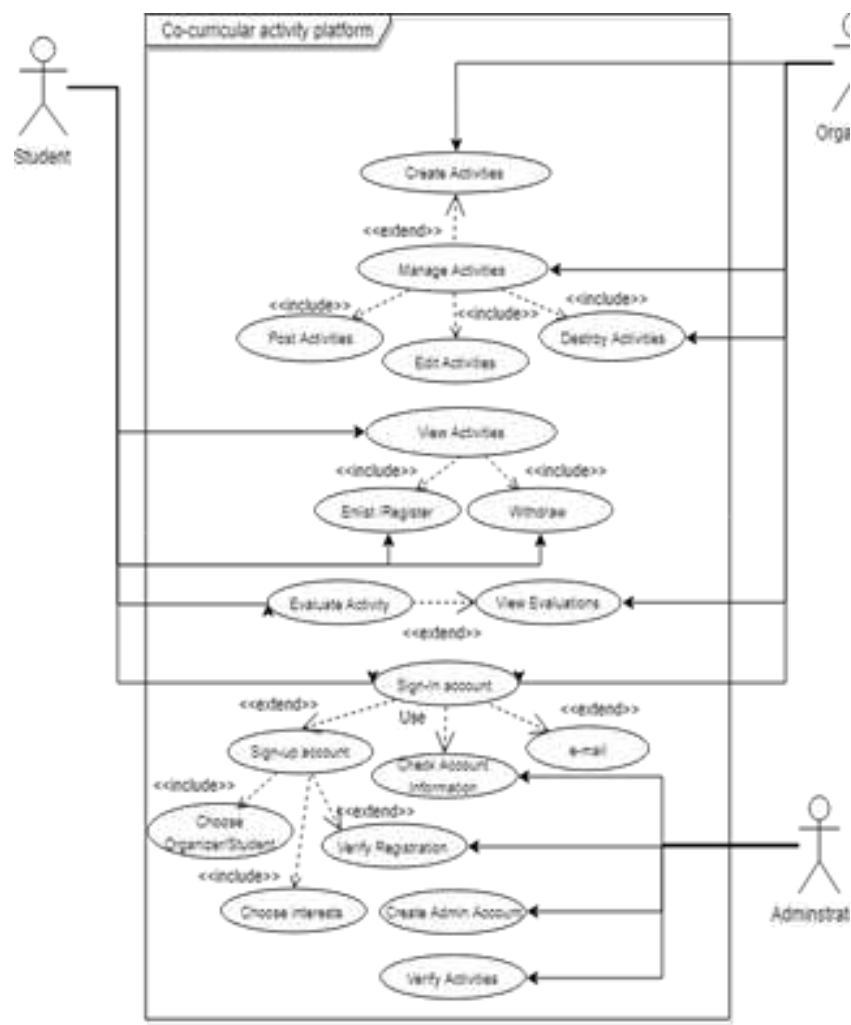

Figure 1. Co-curricular activity management platform use-case diagram.

Table 5. Summary of identified system requirements

\begin{tabular}{|l|}
\hline \multicolumn{1}{|c|}{ Functional Requirements } \\
\hline Search functionality for events and activities \\
\hline Filter of different events and activities for students \\
\hline Search functionality for event and activity organizers \\
\hline $\begin{array}{l}\text { Provide or suggest similar event and activities that students } \\
\text { have interest into }\end{array}$ \\
\hline $\begin{array}{l}\text { Student can see participants that are interested in the same } \\
\text { activity or event }\end{array}$ \\
\hline \multicolumn{1}{|c|}{ Non-Functional Requirements } \\
\hline Performance \\
\hline Reliability \\
\hline Error handling \\
\hline Security \\
\hline Portability \\
\hline Ease of use \\
\hline Responsive user interface \\
\hline
\end{tabular}

C.Co-curricular activity management platform design architecture

The co-curricular activity platform is composed of three layers of logical computing and presented in a 3-tier architecture. The architecture is used because the platform is a specific type of a client-server system. By modularizing the user interface, application logic, and data storage layer, these provide greater flexibility for development teams that decreases development cycle times by allowing them to update modules of the platform independently without affecting the other parts.

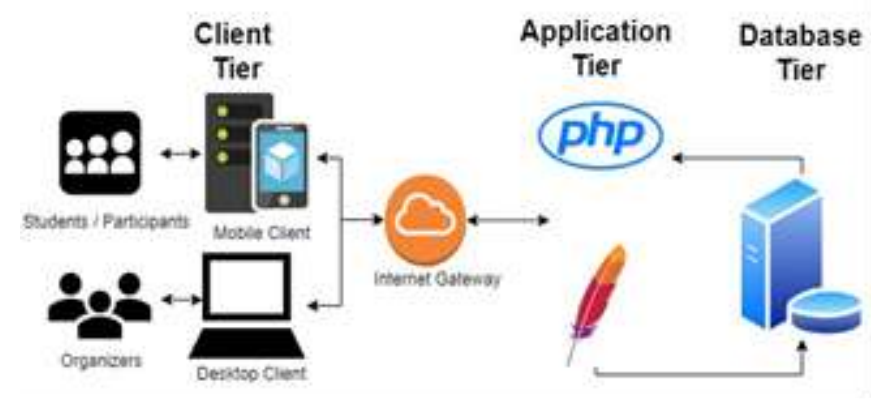

Figure 2. Co-curricular activity management platform design architecture

Figure 2 shows the developed design architecture of a co-curricular activity management platform for students. The design aims to improve student's engagement on co-curricular activities for the all-around development of the students.

The client tier in this model is usually a web browser. As clearly shown from the figure, students or participants of co-curricular activities can access the platform through mobile application. The platform is designed to be entirely web-based providing a native mobile application that can be installed in the mobile phones of the students. The platform will provide information to the students with upcoming activities that are posted by co-curricular activity organizers. The platform will also allow the students to see lists of activities that matches with their interests and preferences and will show lists of participants that want to join in the activity allowing them to expand their friendship network in the campus. On the other hand, by accessing their accounts using desktop clients, the organizers can post upcoming activities, updates, and announcements into the platform, and the platform will disseminate these to the target participants of the activity. The application tier processes all dynamic content and the interactions between the client and persistent or database tier.

The application tier performs as a variety of dynamic gateway. It serves a role in generating dynamic content. Meanwhile, the database tier serves as the database of the web-based application and contains programs for managing read and write access to the database.

\section{CONCLUSION}

The unavailability of features to manage co-curricular activities on existing learning management platforms opted the researcher to construct a design architecture for a co-curricular activity management platform to address the issue. Integrating the ideas and insights gathered on the conducted study, a new design architecture for a co-curricular activity management platform was proposed. In order to evolve architecture continually, the new design provided greater flexibility for development teams that decreases development cycle times by allowing them to update modules of the platform independently without affecting the other parts, and also the design responded to the needs of the 
users, and integrated emerging ICT trends. The tailor fitted design architecture of the platform addressed the specific needs of its end-users, thus providing students more convenient experience and opportunities to engage in co-curricular activities provided by higher educational institutions. As a future work, the next step is the development and deployment of the platform incorporating the design architecture established in this study.

\section{REFERENCES}

1. S. Gunuc, "the Relationships Between Student Engagement and Their Academic Achievement," International Journal on New Trends in Education and their Implication, vol. 5, no. 4, pp. 216 231, 2014.

2. Durlak, J.A., Weissberg, R.P., Dymnicki, A.B., Taylor R.D., Schellinger, K.B., 2011. The impact of enhancing students' social and emotional learning: a meta-analysis of school-based universal interventions. Child Dev. 82 (1) 405-432.

3. C.E. Domitrovich, J.A. Durlak, K.C. Staley, R.P WeissbergSocial-emotional competence: An essential factor for promoting positive adjustment and reducing risk in school children Child Development, 88 (2017), pp. 408-416

4. M.T. Greenberg School-based prevention: Current status and future challenges Effective Education, 2 (2010), pp. 27-52

5. P. Vostanis, N. Humphrey, N. Fitzgerald, J. Deighton, M. Wolpert How do schools promote emotional well-being among their pupils? Findings from a national scoping survey of mental health provision in English schools Child and Adolescent Mental Health, 18 (2013), pp. 151-157

6. C.A. Farrington, M. Roderick, E. Allensworth, J. Nagaoka, T.S. Keyes, D.W. Johnson, N.O. Beechum Teaching adolescents to become learners the role of noncognitive factors in shaping school performance: A critical literature review University of Chicago Consortium on Chicago School Research, Chicago, IL (2012)

7. "Co-curricular Activities: Meaning, Definition, Examples, Importance, Benefits" (n.d.). Retrieved from https://www.gyanunlimited.com/education/co-curricularactivities-meaning-definition-examples-importance-benef its/2437/

8. Aslan, N., Cansever, B.A., 2007. Okuldaki sosyal etkinliklere kat?l?mda ebeveyn-çocuk etkile?imi (kültürleraras? bir kar??la?t?rma). Ege E?itim Dergisi 8 (1), 113-130.

9. Kiper, T., 2009. Nam?k Kemal Üniversitesi ziraat fakültesi ö?rencilerinin rekreasyonele?ilim ve taleplerinin belirlenmesi. Tekirda? Ziraat Fakültesi Dergisi 6 (2), 191-201.

10. Ardahan, F., Lapa, T.Y., 2010. Gelire ve gelinen yerle?im birimine göre ö?rencilerin rekreatif etkinliklere kat?lma ve kat?lmama nedenlerinin de?erlendirilmesi: Akdeniz Üniversitesi örne?i. CBÜ Beden E?itimi ve Spor Bilimleri Dergisi 5 (3), 87-96.

11. Simpkins, S.D., Fredricks, J.A., Davis-Kean, P.E., Eccless, J.S., 2006. Healthy Mind, Healthy Habits: The Influence of Activity Involvement in Middle Childhood. Cambridge University Press, New York.

12. Durualp, E., 2014. Ergenlerin sosyal duygusal ö?renme becerilerinin cinsiyet ve s?n?fa göre incelenmesi. J. Acad. Soc. Sci. Stud. 26, 13-25.

13. Ahmeto?lu, E., 2009. Sosyal geli?im. In: Fazl?o?lu, Y. (Ed.), Erken çocukluk geli?imi ve e?itimi. Kriter Yay?nlar?, ?stanbul, pp. 39-62.

14. Goleman, D., 2012. Emotional Intellenge (Why it can matter more than IQ). In: Çeviri: Banu Seçkin Yüksel,
Duygusal Zeka Neden IQ'dan daha önemlidir? Bask? Varl?k Yay?nlar?, ?stanbul, pp. 35.

15. McKown, C., 2017. Social and emotional learning: a policy vision for the future. The future of children: policy brief. http://dergipark.gov.tr/kuey/issue/10371/126935.

16. Swartz, M.K., 2017. Social and emotional learning. J. Pediatr. Health Care 31 (5), 521-522.

17. Gömleksiz, M.N., Kan, A.Ü., 2012. E?itimde Duyu?sal Boyut ve Duyu?sal Ö?renme. Turk. Stud. Int. Period. Lang. Lit. Hist. Turk. Turkic 7 (1), 1159-1177.

18. Petersen, K.S., 2012. Activities for Building Character and Social-Emotional Learning: Grades 6-8. Free Spirit Publishing, USA E-book.

19. S. Hameed, A. Badii, A. Pervaiz, J. Mellor and A. Cullen, "Impact of the e-learning package on the quality of student learning experience," Proceedings of the European and Mediterranean Conference on Information Systems, EMCIS 2009, pp. 1-15, 2009.

20. Lewis, B. A., MacEntee, V. M., DeLaCruz, S., Englander, C., Jeffrey, T., Takach, E., ... \& Woodall, J. (2005, June). Learning management systems comparison. In Proceedings of the 2005 Informing Science and IT Education Joint Conference (pp. 17-29).

21. M. Kljun, J. Vicic, B. Kavsek and A. Kavcic, "Evaluating Comparisons and Evaluations of Learning Management Systems," 2007 29th International Conference on Information Technology Interfaces, Cavtat, 2007, pp. 363-368.

22. Fenton, W. (2018, January 12) The Best (LMS) Learning Management Systems for 2018. Retrieved from https://www.pcmag.com/roundup/336308/the-best-lms-le arning-management-systems. 